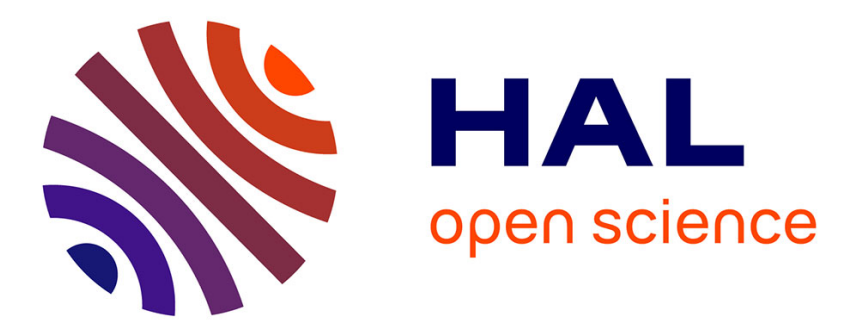

\title{
Impressive response to temsirolimus in a patient with chemotherapy refractory diffuse large B-cell non-Hodgkin's lymphoma
}

Philipp Kiewe, Eckhard Thiel

\section{- To cite this version:}

Philipp Kiewe, Eckhard Thiel. Impressive response to temsirolimus in a patient with chemotherapy refractory diffuse large B-cell non-Hodgkin's lymphoma. Annals of Hematology, 2010, 90 (1), pp.109110. 10.1007/s00277-010-0951-z . hal-00554984

\section{HAL Id: hal-00554984 \\ https://hal.science/hal-00554984}

Submitted on 12 Jan 2011

HAL is a multi-disciplinary open access archive for the deposit and dissemination of scientific research documents, whether they are published or not. The documents may come from teaching and research institutions in France or abroad, or from public or private research centers.
L'archive ouverte pluridisciplinaire HAL, est destinée au dépôt et à la diffusion de documents scientifiques de niveau recherche, publiés ou non, émanant des établissements d'enseignement et de recherche français ou étrangers, des laboratoires publics ou privés. 


\section{Editorial Manager(tm) for Annals of Hematology Manuscript Draft}

Manuscript Number: AOHE-D-10-00147

Title: Impressive response to temsirolimus in a patient with chemotherapy refractory diffuse large Bcell non-Hodgkin's lymphoma

Article Type: Letter to the Editor

Keywords: Temsirolimus; DLCBL; aggressive lymphoma

Corresponding Author: Dr. Philipp Kiewe, M.D.

Corresponding Author's Institution: Charité Campus Benjamin Franklin

First Author: Philipp Kiewe, M.D.

Order of Authors: Philipp Kiewe, M.D.; Eckhard Thiel, M.D.

Abstract: No Abstract - letter to the editor 
Impressive response to temsirolimus in a patient with chemotherapy refractory diffuse large B-cell non-Hodgkin's lymphoma

Philipp Kiewe* and Eckhard Thiel

Dept. of Hematology, Oncology and Transfusion Medicine, Charité University

Medicine, Campus Benjamin Franklin, Hindenburgdamm 30/31, 12200 Berlin, Germany

${ }^{*}$ Charité University Medicine, Campus Benjamin Franklin

Dept. of Hematology, Oncology and Transfusion Medicine

Hindenburgdamm 30

D-12200 Berlin, Germany

Tel.: +49-30-8445-2337

Fax: $+49-30-8445-4468$

Email: philipp.kiewe@charite.de

Keywords: Temsirolimus; DLCBL; aggressive lymphoma 


\section{Dear Editor,}

Temsirolimus is a selective inhibitor of the cell proliferation promoting intracellular protein mTOR (mammalian target of rapamycin). Its activity in lymphatic malignancies has first been demonstrated in relapsed mantle-cell lymphoma [1]. Further studies confirmed activity in this lymphoma entity and established a weekly dosage of $75 \mathrm{mg}$ as approved treatment regimen [2], although a weekly dose of $25 \mathrm{mg}$ remains an effective treatment option [3]. Experience with temsirolimus in other entities of $\mathrm{NHL}$ is limited to a phase II study in recurrent DLCBL, follicular lymphoma and chronic lymphocytic leukemia/small lymphocytic lymphoma [4]. In 19 evaluable patients with DLCBL and a median of $\geq 2$ prior treatment lines, a remarkable overall response rate of $42 \%$ was observed with a weekly temsirolimus dosage of only 25mg.

\section{A 44-year old woman was diagnosed with diffuse-large B-cell Non-Hodgkin's} lymphoma (NHL) limited to the tongue base (stage IBE) in June 2003. After initial treatment with 6 cycles of dose-intensified cyclophosphamide, adriamycin, vincristine, etoposide and prednisolone (Hi-CHOEP), a complete response was achieved. The patient relapsed in October 2006 with intrathoracic and abdominal manifestations. Salvage therapy included 3 cycles of rituximab, ifosfamide, carboplatin and etoposide (R-ICE) followed by high-dose carmustine, etoposide, cytarabine, melphalan (HDBEAM) and autologous stem-cell transplantation resulting in complete response. In July 2008, second relapse occurred with cervical and abdominal lymph node enlargements. Treatment was initiated with 5 cycles of rituximab and bendamustine yielding another complete response. Remission, however, was short-lived, and in January 2009 disease recurred. Sequential treatment included one cycle of rituximab, dexamethasone, high-dose cytarabine, cisplatin (R-DHAP) and one cycle of 
rituximab, high-dose cytarabine, mitoxantrone (dose-modified R-HAM) in reconfirmed CD20-positive disease followed by a second high-dose protocol with ${ }^{90} \mathrm{Y}$-ibritumomab tiuxetan, cyclophosphamide, etoposide, carmustine (Z-CVB) and autologous stemcell support. This time, only partial remission was achieved with disease progression shortly thereafter in August 2009. Further treatment lines including lenalidomide, two cycles each of gemcitabine/mitoxantrone and carboplatin/ifosfamide were ineffective. In November 2009 the patient presented with a large intraabdominal tumor-bulk resulting in a massively distended abdomen. Lactate dehydrogenase (LDH) had risen to $480 \mathrm{U} / \mathrm{L}(<247)$ and bone marrow function was poor with severe tricytopenia, predominantly thrombocytopenia of $50 \times 10^{9} / /(150-400)$.

At this time, weekly monotherapy with $25 \mathrm{mg}$ temsirolimus was started. A dramatic clinical response was seen after only 5 infusions with normalization of the abdominal exam and LDH. No relevant toxicity was noted. The sixth temsirolimus infusion was combined with bendamustine after platelet counts had risen to $136 \times 10^{9} /$. One week thereafter, restaging computed tomography (CT) scans confirmed clinical response with only minimal residual abdominal lymphoma manifestations compared with pretreatment imaging (Fig 1a+b). Temsirolimus infusions were continued but unfortunately, tumor progression was observed four weeks later.

The very favourable response in our patient with highly pretreated refractory DLCBL, though short-lived, supports the evidence of a high activity of temisirolimus in $\mathrm{NHL}$ including DLCBL. Further investigations are clearly warranted, preferably in less advanced disease and in combination with chemotherapy. Moreover, the optimal dosage needs to be defined. 
Figure 1 Abdominal CT scan without intravenous contrast-enhancement before

temsirolimus treatment (a) and after six weekly infusions (b) showing only minimal residual lymphoma manifestations (arrow).

\section{References:}

1. Witzig TE, Geyer SM, Ghobrial I, et al (2005) Phase II trial of single-agent temsirolimus (CCl-779) for relapsed mantle cell lymphoma. J Clin Oncol 23:53475356.

2. Hess G, Herbrecht R, Romaguera J, et al (2009) Phase III study to evaluate temsirolimus compared with investigator's choice therapy for the treatment of relapsed or refractory mantle cell lymphoma. J Clin Oncol 27:3822-3829.

3. Ansell SM, Inwards DJ, Rowland KM Jr, et al (2008) Low-dose, single-agent temsirolimus for relapsed mantle cell lymphoma: a phase 2 trial in the North Central Cancer Treatment Group. Cancer 113:508-514.

4. Smith SM, Pro B, Cisneros A, et al (2008) Activity of single agent temsirolimus (CCl-779) in non-mantle cell non-Hodgkin lymphoma subtypes. J Clin Oncol 26:15s (suppl; abstr 8514). 


\section{A}

[A]

Study Date:25,09,2009

Study Time: $11: 49.68$

MRN:

[A]

B

Study Date:21.01.2010

Study Time: $12.04: 56$

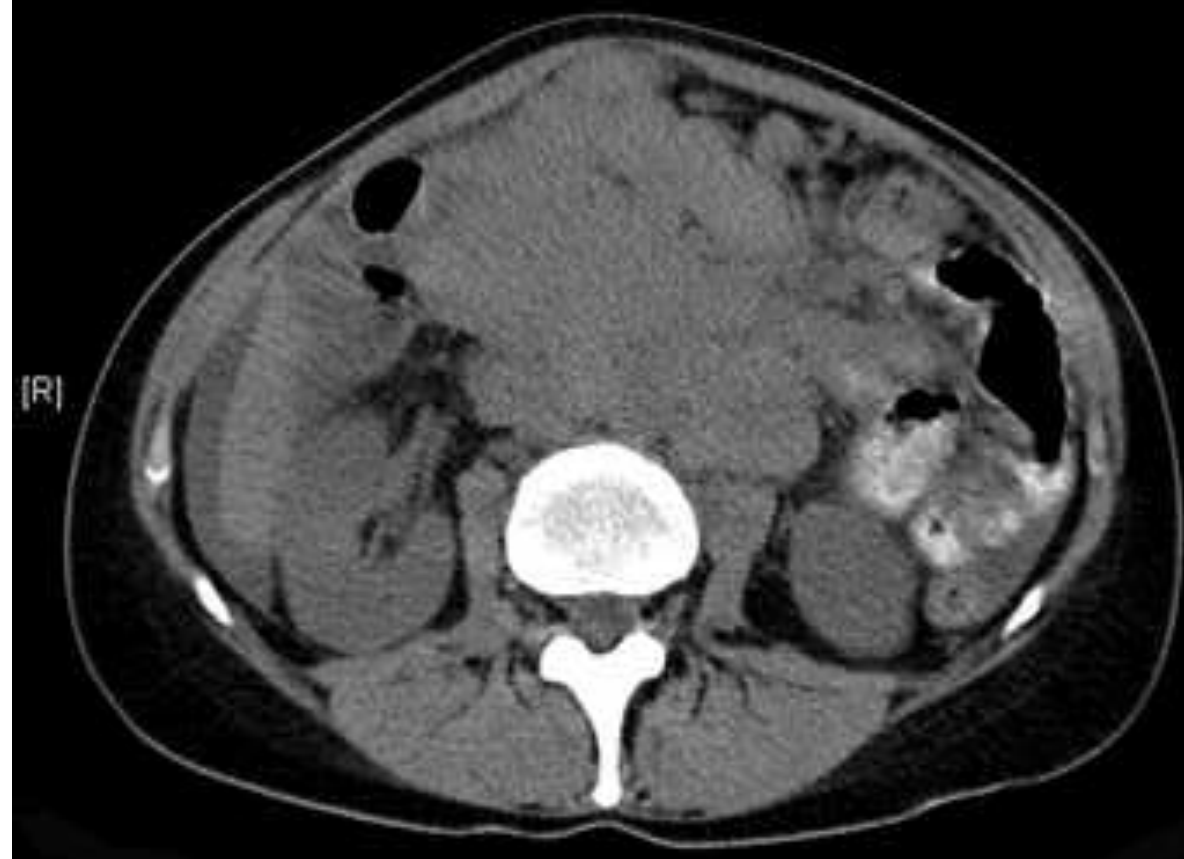

Before treatment

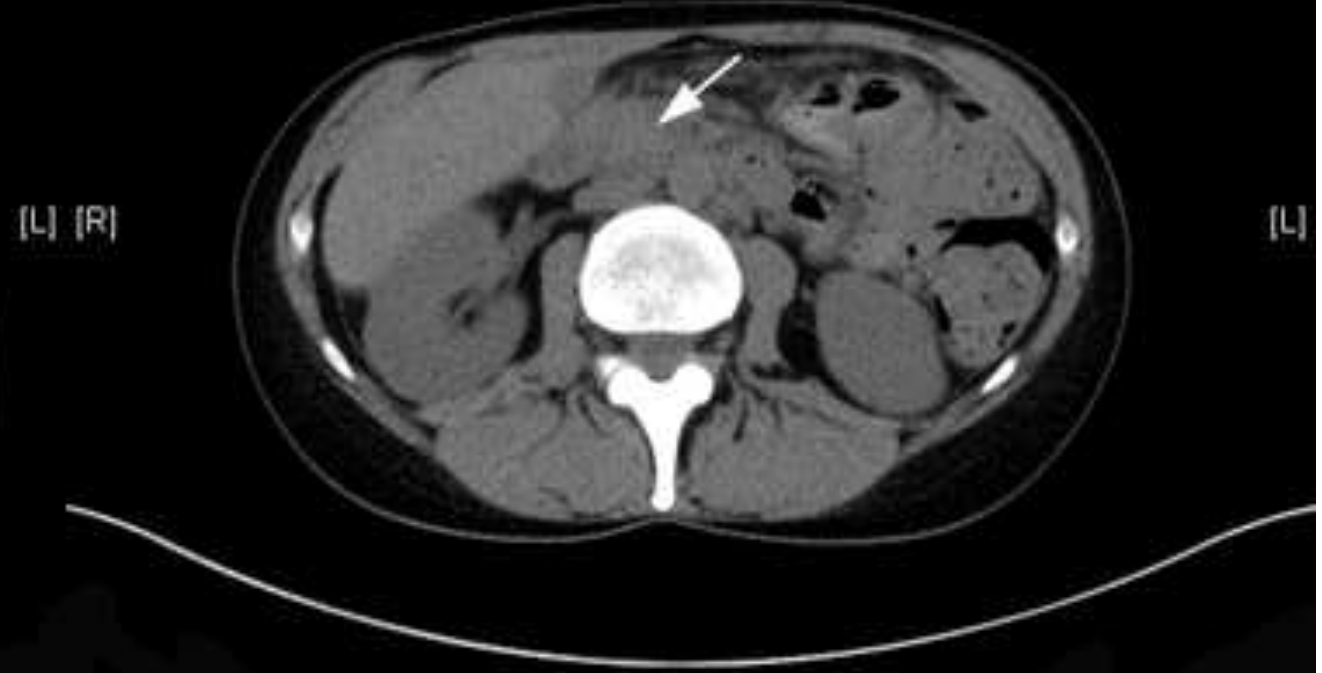

After 6 infusions of temsirolimus 
Click here to download Conflict of interest: conflictofinterestdisclosureform.pdf

To be submitted offline

Click here to download Conflict of interest: conflictofinterestdisclosureform.pd

$\sqrt{10}$

(1)

(1)

(1)

$\sqrt{10}$

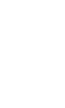
(1)

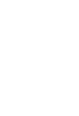

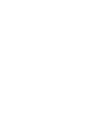

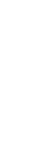

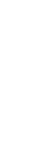
.

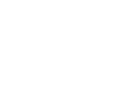
.

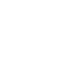

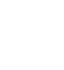

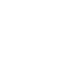

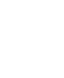

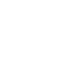
更

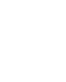

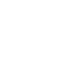

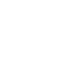
更

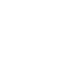

